Brazilian Journal
of Chemical
Engineering

ISSN 0104-6632

Printed in Brazil

www.abeq.org.br/bjche

Vol. 26, No. 03, pp. 481 - 492, July - September, 2009

\title{
LEACHATE TREATMENT PROCESS AT A MUNICIPAL STABILIZED LANDFILL BY CATALYTIC OZONATION: AN EXPLORATORY STUDY FROM TAGUCHI ORTHOGONAL ARRAY
}

\author{
A. L. C. Peixoto ${ }^{*}$, M. B. Silva and H. J. Izário Filho \\ Department of Chemical Engineering, Engineering School of Lorena (ESL), \\ Phone: + (55) (12) 3159-5076, University of São Paulo (USP), Estrada Municipal do Campinho s/no \\ Bairro do Campinho, Lorena - SP, Brazil. \\ E-mail: alcpeixoto@gmail.com
}

(Submitted: September 6, 2008 ; Revised: December 20, 2008 ; Accepted: December 23, 2008)

\begin{abstract}
Catalytic ozonation has been recognized in the scientific community as an efficient technique, reaching elevated rates of recalcitrant organic material mineralization, even at the presence of scavenger species of hydroxyl free radicals. This study presents the most significant factors involving the leachate treatment stabilized by the municipal landfill of the city of Guaratinguetá, State of São Paulo, Brazil, by using a catalytic ozonation activated by metallic ions $\mathrm{Fe}^{3+}, \mathrm{Zn}^{2+}, \mathrm{Mn}^{2+}, \mathrm{Ni}^{2+}$ and $\mathrm{Cr}^{3+}$. The Taguchi $\mathrm{L}_{16}$ orthogonal array and its associated statistical methods were also used in this study. Among the researched ions, the most notable catalysis was obtained with ferric ion, statistically significant in the reduction of COD with a confidence level of $99.5 \%$.

Keywords: Taguchi orthogonal arrays; Catalytic ozonation; Metallic ions; Mature leachate.
\end{abstract}

\section{INTRODUCTION}

In the context of water treatment technologies, ozone has been highlighted due to its high oxidation level $\left(\mathrm{E}^{0}=2.1 \mathrm{~V}\right)$ and strong disinfection power (eliminating virus and bacteria). It is applied with the aim to improve the taste and color as well as the removal of organic and inorganic components. Among ordinary chemical substances, only fluorine has a higher reduction potential than ozone $\left(\mathrm{E}^{0}=3.0\right.$ V). Other commonly oxidants used such as $\mathrm{KMnO}_{4}$ $\left(\mathrm{E}^{0}=1.7 \mathrm{~V}\right)$ and $\mathrm{Cl}_{2}\left(\mathrm{E}^{0}=1.4 \mathrm{~V}\right)$ can form byproducts (metallic heavy ions and organochlorine compounds, respectively) that may be more toxic than the original pollutant compounds. Here, the second advantageous property of ozone is evident because its preferential degradation product is oxygen, a non-pollutant product and important for aerobic biological activities of aquatic ecosystems (Mahmoud and Freire, 2007).

In spite of several advantages ozone offers, there are also some disadvantages limiting its application on a large scale in relation to the treatment technology of water. The mainly disadvantages are the solubility $\left(0.57 \mathrm{~g} \mathrm{~L}^{-1}\right.$ in pure water at $\left.20^{\circ} \mathrm{C}\right)$ and low stability (half lifetime of $20 \mathrm{~min}$ in pure water, neutral $\mathrm{pH}$ and temperature at $20^{\circ} \mathrm{C}$ ) (Battino, 1992) allied to the higher energetic cost of ozone production (12 to $18 \mathrm{kWh} \mathrm{kg}^{-1}$ ), besides the partial oxidation of organic compounds present in the water due to direct action or molecular oxygen (KasprzykHordern et al., 2003).

*To whom correspondence should be addressed 
With the aim of promoting more efficiency of the processes based on ozonation and also with the objective of reducing energetic costs associated with the ozone generation, different methods of advanced oxidation (AOPs) have been studied. These methods promote the indirect action of ozone on the organic material via the hydroxyl free radical $\left({ }^{\bullet} \mathrm{OH}\right)$, generated in situ, with an elevated oxidation potential $\left(\mathrm{E}^{0}=2.8 \mathrm{~V}\right)$.

Among these methods can be mentioned: $\mathrm{O}_{3} / \mathrm{OH}^{-}$ (Legrini et al., 1993), $\mathrm{O}_{3} / \mathrm{UV}$ (Legrini et al., 1993), $\mathrm{O}_{3} / \mathrm{H}_{2} \mathrm{O}_{2}$ (Legrini et al., 1993), $\mathrm{O}_{3} / \mathrm{H}_{2} \mathrm{O}_{2} / \mathrm{UV}$ (Legrini et al., 1993, Wu et al., 2004, Tizaoui et al., 2007), heterogeneous catalytic ozonation (with or without UV irradiation) (Andreozzi et al., 1998, Khan and Jung, 2008, Valdés et al., 2008) and homogeneous catalytic ozonation (with or without UV irradiation) (Andreozzi et al., 1998, Beltrán et al., 2005, Khan and Jung, 2008, Wu et al., 2008).

Catalytic ozonation constitutes an important treatment technology for the removal of refractory compounds by ozonation through a direct or indirect process. It is capable of attaining elevated rates of organic material mineralization, mainly in acid medium, not being observed in the conventional process of ozonation due to the formation of refractory by-products. In addition, scavengers of hydroxyl radicals such as carbonates do not interfere in the catalytic process of ozonation, most probably because of complex formation between a metallic ion and a contaminant that will be oxidized by ozone (Assalin and Durán, 2007). At first, catalytic ozonation may be considered as a homogeneous process based on the activation of ozone by metallic ions present in an aqueous solution; and then as a heterogeneous process with the presence of metallic oxides or supported metallic oxides (KasprzykHordern et al., 2003).

The proposed catalysts for the homogeneous process of catalytic ozonation are transition metal cations, as for example $\mathrm{Fe}^{2+}, \mathrm{Mn}^{2+}, \mathrm{Ni}^{2+}, \mathrm{Co}^{2+}, \mathrm{Cd}^{2+}$, $\mathrm{Cu}^{2+}, \mathrm{Ag}^{+}, \mathrm{Cr}^{3+}$ and $\mathrm{Zn}^{2+}$. The nature of the transition metal applied determines not only the reaction rate but also the selectivity of ozone consumption (KasprzykHordern et al., 2003). Equation 1 shows ozone activation by metallic ions in general (Hill, 1948, Hill, 1949, Legube and Leitner, 1999, Beltrán et al., 2005).

$\mathrm{M}^{\mathrm{n}+}+\mathrm{O}_{3}+\mathrm{H}_{2} \mathrm{O} \rightarrow \mathrm{MOH}^{\mathrm{n}+}+\mathrm{O}_{2}+{ }^{\bullet} \mathrm{OH}$

The original metal oxidation state can be reestablished due to parallel radicals according to
Equation 2.

$\mathrm{HO}_{2}^{\bullet}+\mathrm{MOH}^{\mathrm{n}+} \rightarrow \mathrm{M}^{\mathrm{n}+}+\mathrm{O}_{2}+\mathrm{H}_{2} \mathrm{O}$

This work aims at selecting and proposing the best adjustment of significant factors in the degradation of organic compounds of recalcitrant leachate coming from the old landfill of the city of Guaratinguetá (State of São Paulo), exclusively by the catalytic ozonation method (ions $\mathrm{Fe}^{3+}, \mathrm{Zn}^{2+}$, $\mathrm{Mn}^{2+}, \mathrm{Ni}^{2+}$ and $\mathrm{Cr}^{3+}$ ), treating the leachate sampled in the landfill. For the study of the variables used in this catalytic process, a Taguchi $\mathrm{L}_{16}$ orthogonal array was applied as well as its associated statistical methods.

\section{MATERIALS AND METHODS}

\section{Sample and Preservation}

Two hundred liters of leachate from the regulated older landfill of the city of Guaratinguetá (State of São Paulo, Brazil) were collected to perform a study and a treatment of effluent by catalytic ozonation. After the collection, the effluent was conditioned at $4^{\circ} \mathrm{C}$ to minimize alterations of its physical-chemical properties (APHA, 1999).

\section{Determination of the Analytical Parameters COD and BOD}

All analytical determinations were performed according to Standard Methods (APHA, 1999) and norms L5 CETESB. COD determinations were performed with assimilation in a closed tube, followed by spectrophotometric determination (Fentom 600 spectrophotomer) at $620 \mathrm{~nm}$ (APHA, 1999). For determinations of $\mathrm{BOD}_{5}$, in natura and chemically treated leachate samples were incubated (Marconi incubator Inc., Model MA 415S) for a period of 5 days with inoculation of microorganisms as Seed, $20 \pm 3^{\circ} \mathrm{C}$; the measure of oxygen before and after the incubation was performed by Winkler's titrimetric method modified by sodium azide (APHA, 1999; Lima et al., 2006). Analytical determinations of COD and BOD of the treated leachate samples were performed immediately after the conclusion of each experiment of homogeneous catalytic ozonation. There was no previous filtration of the samples for the respective analysis of COD and BOD (Peixoto et al., 2008). 
Determining Analytical Parameters for $\mathbf{p H}$, $\mathrm{N}-\mathrm{Org}, \mathrm{N}-\mathrm{NH}_{3}$, Phenol, Soluble in n-Hexane and Phosphorus

The mineral acids were provided by Dinâmica, the organic solvents by Reagen, and the other chemical reactants by Vetec. The $\mathrm{pH}$ of the in natura leachate was determined on the effluent sample using a Digimed pHmeter, Model DM-22. The procedure to determine organic nitrogen, [NOrg], and ammonia, $\left[\mathrm{N}-\mathrm{NH}_{3}\right]$, concentrations, was the distillation of gaseous ammonia, by increasing $\mathrm{pH}$ via sodium hydroxide (in the presence of buffer solution) (CETESB, 1978). The distilled ammonia was then absorbed by boric acid solution. For the organic nitrogen determination, after removing ammonia by distillation, the nitrogen is converted into ammonium sulfate by digestion with sulfuric acid, potassium sulfate, and mercury sulfate as a catalyst. The digested product was then treated with a solution of sodium thiosulfate in alkaline medium and the resulting ammonia was distilled. The distilled product was converted into a stable complex with Nessler reactant (Nesslerization), with spectrophotometric determination at $420 \mathrm{~nm}$. To determine the concentration of phenols, the sample was initially distilled to remove non-volatile impurities in the presence of phosphoric acid, and cupric sulfate as a catalyst. 4-Aminoantipirin, when treated with a weak oxidant (potassium ferricyanide) at $\mathrm{pH} 7.9 \pm 0.1$, reacts with fenolic compounds present in the distillation, forming a product extractable into chloroform with an intense absorption at $460 \mathrm{~nm}$ (CETESB, 1975). The most recommended method for oil and grease determination [n-hexane] is the extraction with an organic solvent by a Soxhlet apparatus, known as Soxhlet method (CETESB, 1991). The leachate sample was, initially, acidified to promote the breaking of emulsions, helping the separation of oil. The sample was then filtered through mousseline cloth mesh, filter paper and auxiliary suspension of diatomaceous earth. After being filtered and dried at $103^{\circ} \mathrm{C}$ in an incubator, the retained material in the filter was extracted (Soxhlet system) in nhexane, under reflux for 4 hours. After the period of extraction, distillation of the hexane in which the oil was dissolved was done and, then, the residue dried at $80^{\circ} \mathrm{C}$ in an incubator, avoiding degradation of the extracted product. After that, a gravimetric analysis of the oil residue was performed on an analytical balance (ADA analytical balance, Model 210/L). Analysis of phosphorus in effluents was done by spectrophotometry where orthophosphates combine with mixed reagent (ammonium molybdate solution and ammonium metavanadate), forming a yellow complex that has its maximum absorption at $470 \mathrm{~nm}$. Organic phosphates need chemical digestion, employing as digestion reactants, for the leachate sample, sulfuric and nitric acids. When making the previous digestion, total phosphorus concentration is obtained (APHA, 1999).

\section{Rate Production of Ozone}

The ozone used in experimental treatments of leachate was produced by the conversion of $\mathrm{O}_{2}$ to $\mathrm{O}_{3}$ through the use of an Auje Inc. equipment, Model MV 01. The generation of ozone resulted from the electric discharge method by dielectric-barriers (Corona effect) with the following operational characteristics: nominal tension of $220 \mathrm{~V}$, maximum potential of $60 \mathrm{~W}$ and working pressure of 2 bars. From the ozonizer stage until the final experimental treatment of the landfill leachate, an ozone-feeding generator was used with oxygen (AGA) of a nominal purity of $99.99 \%$. Before studying the leachate treatment by homogeneous catalytic ozonation, the mass production rate of ozone by the referred equipment was determined. Ozone exit flows were selected at 3,5 and $7 \mathrm{~L} \mathrm{~h}^{-1}$. The analytical methodology applied in determining the generated ozone was the traditional iodometry with tritation of iodine by sodium thiosulfate and starch as an oxireduction indicator (Fifield and Kealey, 2000, Kurniawan et al., 2006).

\section{Treatment of in natura Landfill Leachate by Catalytic Ozonation in a Semi-Batch System}

The performance of all leachate treatment stages was done in a reactor consisting of a borosilicate glass sheath, with water recirculation at a constant temperature of $25^{\circ} \mathrm{C}$. The ozone injection inside the chemical reactor was performed at its base, through a $3 \mathrm{~mm}$ thick, sintered glass plate with a maximum porosity of $16 \mu \mathrm{m}$. Figure 1 shows the dimensions of the glass reactor used. In all experiments of leachate treatment by catalytic ozonation, $900 \mathrm{~mL}$ of effluent was used to keep a constant value of ozone gas flow and $\mathrm{pH}$ of the reaction medium during the period of reaction $(30 \mathrm{~min})$. In the treatment of leachate, a germicidal lamp (wavelength of $253.7 \mathrm{~nm}$ ), GE brand, with a potential of $16 \mathrm{~W}$ enclosed in a quartz tube immersed in the effluent was also used. 


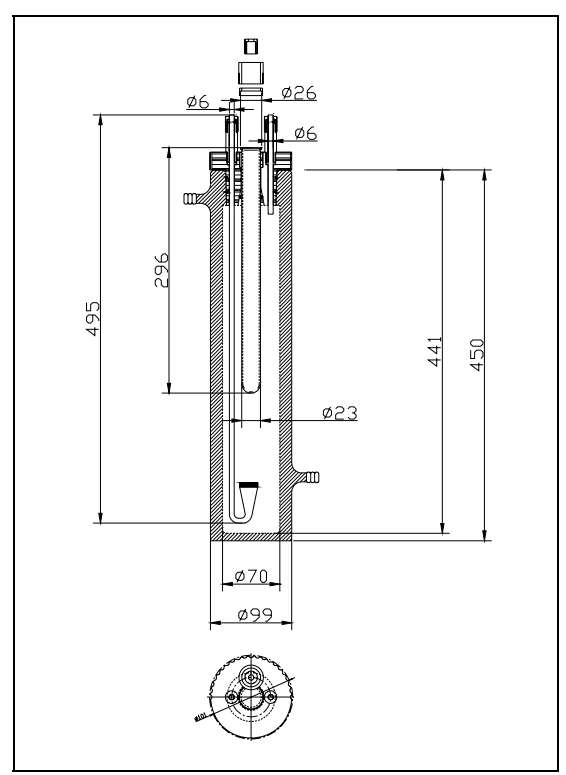

Figure 1: Dimensions, in $\mathrm{mm}$, of the glass borosilicate reactor used in the leachate treatment by homogeneous catalytic ozonation.

The exploratory study with selected factors for the leachate treatment by catalytic ozonation with transition metals combined with (UV) photocatalysis was evaluated according to the experimental design with the Taguchi $\mathrm{L}_{16}$ orthogonal array (Table 1), with a real replicate of experimental conditions, resulting in a total of 32 experiments. The reduced time (30 min) of chemical reaction was chosen at this exploratory stage to identify the factors involved in the leachate treatment by catalytic ozonation, it not being our purpose to look for optimum conditions of mineralization. Selçuk et al. (2006) studied the effect of ozonation treatment of the final residue of the textile industry in Istanbul, Turkey, providing variable results for acute toxicity with Daphnia magna and COD. In that study, the authors also used the reaction time of $30 \mathrm{~min}$, with mass flow of ozone equal to $18.5 \mathrm{mg} \mathrm{min}^{-1}$.

The analyzed factors were: ozone flow (factor $A$, column 4), transition metal concentrations of $\mathrm{Fe}^{3+}$ (factor $B$, column 5), $\mathrm{Zn}^{2+}$ (factor $C$, column 6), $\mathrm{Mn}^{2+}$ (factor $D$, column 7), $\mathrm{Ni}^{2+}$ (factor $E$, column 8 ), $\mathrm{Cr}^{3+}$ (factor $F$, column 9), $\mathrm{pH}$ of the reaction medium (factor $G$, column 10) and influence of ultraviolet irradiation (factor $H$, column 11). Table 2 shows the level values of the different factors used in the experimental design from Taguchi $L_{16}$. Selected values for the different factors, according to Table 2, were based on Article 18 of the São Paulo State Decree No 8.468 of September 8, 1976 (São Paulo, 2008), which governs physical and chemical conditions of the effluent for discarding into receptors. These transition metal ions were chosen because they are found in municipal landfill leachate, aiming at using the intrinsic chemical characteristics of leachate to power the ozone treatment. Basic $\mathrm{pH}$ was chosen as a high level to facilitate the solubilization of humic fraction present in the recalcitrant effluent, thus facilitating the chemical degradation. The acid $\mathrm{pH}$ facilitates the solubilization of metallic ions.

Table 1: The Taguchi $L_{16}$ orthogonal array used for the exploratory study of leachate treatment by catalytic ozonation

\begin{tabular}{|c|c|c|c|c|c|c|c|c|c|c|c|c|c|c|c|}
\hline \multirow[b]{2}{*}{$\mathbf{N}$} & \multicolumn{15}{|c|}{ Column number } \\
\hline & 1 & 2 & 3 & 4 & 5 & 6 & 7 & 8 & 9 & 10 & 11 & 12 & 13 & 14 & 15 \\
\hline 1 & 1 & 1 & 1 & 1 & 1 & 1 & 1 & 1 & 1 & 1 & 1 & 1 & 1 & 1 & 1 \\
\hline 2 & 1 & 1 & 1 & 1 & 1 & 1 & 1 & 2 & 2 & 2 & 2 & 2 & 2 & 2 & 2 \\
\hline 3 & 1 & 1 & 1 & 2 & 2 & 2 & 2 & 1 & 1 & 1 & 1 & 2 & 2 & 2 & 2 \\
\hline 4 & 1 & 1 & 1 & 2 & 2 & 2 & 2 & 2 & 2 & 2 & 2 & 1 & 1 & 1 & 1 \\
\hline 5 & 1 & 2 & 2 & 1 & 1 & 2 & 2 & 1 & 1 & 2 & 2 & 1 & 1 & 2 & 2 \\
\hline 6 & 1 & 2 & 2 & 1 & 1 & 2 & 2 & 2 & 2 & 1 & 1 & 2 & 2 & 1 & 1 \\
\hline 7 & 1 & 2 & 2 & 2 & 2 & 1 & 1 & 1 & 1 & 2 & 2 & 2 & 2 & 1 & 1 \\
\hline 8 & 1 & 2 & 2 & 2 & 2 & 1 & 1 & 2 & 2 & 1 & 1 & 1 & 1 & 2 & 2 \\
\hline 9 & 2 & 1 & 2 & 1 & 2 & 1 & 2 & 1 & 2 & 1 & 2 & 1 & 2 & 1 & 2 \\
\hline 10 & 2 & 1 & 2 & 1 & 2 & 1 & 2 & 2 & 1 & 2 & 1 & 2 & 1 & 2 & 1 \\
\hline 11 & 2 & 1 & 2 & 2 & 1 & 2 & 1 & 1 & 2 & 1 & 2 & 2 & 1 & 2 & 1 \\
\hline 12 & 2 & 1 & 2 & 2 & 1 & 2 & 1 & 2 & 1 & 2 & 1 & 1 & 2 & 1 & 2 \\
\hline 13 & 2 & 2 & 1 & 1 & 2 & 2 & 1 & 1 & 2 & 2 & 1 & 1 & 2 & 2 & 1 \\
\hline 14 & 2 & 2 & 1 & 1 & 2 & 2 & 1 & 2 & 1 & 1 & 2 & 2 & 1 & 1 & 2 \\
\hline 15 & 2 & 2 & 1 & 2 & 1 & 1 & 2 & 1 & 2 & 2 & 1 & 2 & 1 & 1 & 2 \\
\hline 16 & 2 & 2 & 1 & 2 & 1 & 1 & 2 & 2 & 1 & 1 & 2 & 1 & 2 & 2 & 1 \\
\hline
\end{tabular}


Table 2: Values used by the Taguchi $L 16$ orthogonal array for flow factors in $L ~^{-1}$, of ozone $(A)$, concentrations in $\mathrm{mg} \mathrm{L}^{-1}$, of $\mathrm{Fe}^{3+}$ ions $(B), \mathrm{Zn}^{2+}(C), \mathrm{Mn}^{2+}(D), \mathrm{Ni}^{2+}(E), \mathrm{Cr}^{3+}(F)$, $\mathrm{pH}(G)$ of reaction medium and influence of $\mathrm{UV}(\mathrm{H})$ irradiation with presence of germicidal lamp.

\begin{tabular}{|c|c|c|c|c|c|c|c|c|}
\hline \multirow{2}{*}{ Levels } & \multicolumn{9}{|c|}{ Factors } \\
\cline { 2 - 9 } & $\mathbf{A}$ & $\mathbf{B}$ & $\mathbf{C}$ & $\mathbf{D}$ & $\mathbf{E}$ & $\mathbf{F}$ & $\mathbf{G}$ & H \\
\hline 1 & 3.0 & 10.0 & 2.5 & 0.5 & 1.0 & 2.5 & 5.0 & Absence \\
2 & 5.0 & 20.0 & 5.0 & 1.0 & 2.0 & 5.0 & 8.0 & Presence \\
\hline
\end{tabular}

The addition of ferric ion was performed from a 0.1 eq $\mathrm{L}^{-1}$ stock solution of $\mathrm{Fe}\left(\mathrm{NO}_{3}\right)_{3} \cdot 9 \mathrm{H}_{2} \mathrm{O}$. The stock solution was determined by dicromatometry via the reduction of ferric ion to ferrous with the help of stannous chloride $5 \% \mathrm{~m} \mathrm{v}^{-1}$ (Fifield and Kealey, 2000). Other metallic ions were added to the effluent from Tritsol Merck standards with concentrations of $1000 \mathrm{mg} \mathrm{L}^{-1}$. Adjustment of reaction $\mathrm{pH}$ was performed with stock-solutions of $\mathrm{H}_{2} \mathrm{SO}_{4} \quad 0.1$ eq $\mathrm{L}^{-1}$ and $\mathrm{NaOH} \quad 0.1$ eq $\mathrm{L}^{-1}$. The monitoring of $\mathrm{pH}$ was performed with a combination electrode with a glass membrane and reference electrode of silver / silver chloride, in Digimed Inc. pHmeter, Model DM-22.

The chemical oxygen demand (COD) was used as the variable response, being a consolidated parameter easily determined (Peixoto et al., 2008). Other variables used to accompany the exploratory and treatment stage were the biochemical oxygen demand $\left(\mathrm{BOD}_{5}\right)$ and the $\mathrm{BOD} / \mathrm{COD}$ ratio (biotreatability factor).

\section{RESULTS AND DISCUSSION}

This work utilizes in natura leachate from the regulated older landfill of the city of Guaratinguetá, State of São Paulo, Brazil, deactivated in 2006 and transformed into an Ecological Park after approximately 30 years of work. This study of leachate presents the following principal characteristics $\mathrm{COD}=$ $(1013 \pm 51) \mathrm{mg} \mathrm{L}^{-1}$, BOD $<5.0 \mathrm{mg} \mathrm{L}^{-1}$ and $\mathrm{TOC}=$ (286.5 \pm 26.9$) \mathrm{mg} \mathrm{L}^{-1}$. Other analytical and evaluated parameters, aiming at the in natura leachate characterization, were: $\mathrm{pH}=8.05 \pm 0.21$, [phenols] $=$ $(0.42 \pm 0.01) \mathrm{mg} \mathrm{L}^{-1}$, [phosphorus] $=(8.69 \pm 0.01)$ $\mathrm{mg} \mathrm{L}^{-1},\left[\mathrm{~N}^{-\mathrm{NH}_{3}}\right]=(398 \pm 122) \mathrm{mg} \mathrm{L}^{-1},[\mathrm{~N}-\mathrm{Org}]=$ $(29 \pm 22) \mathrm{mg} \mathrm{L}^{-1} \mathrm{e}$ [n-hexane] $<5.0 \mathrm{mg} \mathrm{L}^{-1}$.

Firstly, the calibration of the ozone generator used in the study of recalcitrant leachate treatment was performed, providing the mass production rate of ozone according to Figure 2.

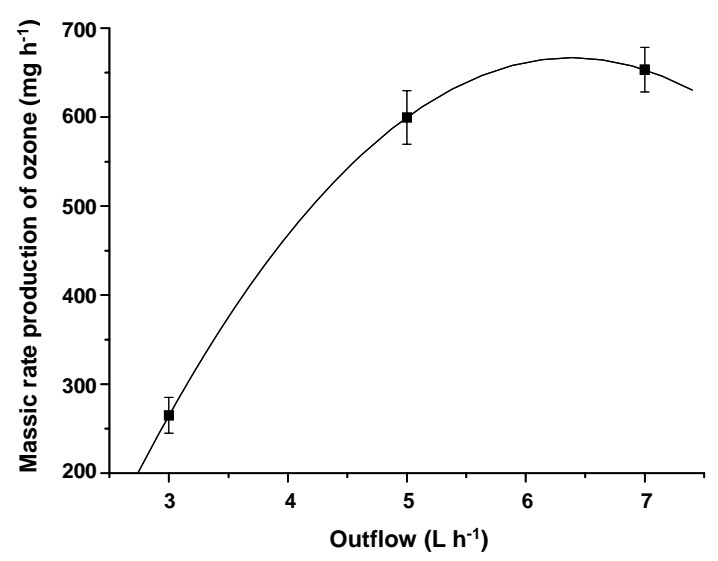

Figure 2: Mass production of ozone $\left(\mathrm{mg} \mathrm{h}^{-1}\right)$ vs. the output flow of ozone $\left(\mathrm{L} \mathrm{h}^{-1}\right)$ from the ozonizer $(\mathrm{N}=2)$.

According to Figure 2, mass productions of (265 \pm 20$),(600 \pm 30)$ and $(653 \pm 25) \mathrm{mg} \mathrm{h}^{-1} \mathrm{O}_{3}$ for flows of 3,5 and $7 \mathrm{~L} \mathrm{~h}^{-1}$, are verified, respectively. An increase of the ozone production of approximately 126 $\%$ was also observed with an alteration from 3 to $5 \mathrm{~L} \mathrm{~h}^{-}$ ${ }^{1}$ in the output flow. With the alteration of the output flow from 5 to $7 \mathrm{~L} \mathrm{~h}^{-1}$, therefore, the increase of the ozone generation amounts to only $9 \%$. This way, the output flows of 3 and $5 \mathrm{~L} \mathrm{~h}^{-1}$ were used in the experiments of leachate treatments by catalytic ozonation.

After finishing the determination of the mass production of ozone, a treatment of leachate by catalytic ozonation was performed. Table 3 shows the experimental results obtained in the treatment of in natura leachate according to the Taguchi $\mathrm{L}_{16}$ orthogonal array. The experimental data is distributed in two different sets representing real duplicates of each experimental condition proposed by the exploratory study. 
Table 3: Minimum, maximum and mean values of COD $\left(\mathrm{mg} \mathrm{L}^{-1}\right)$, and respective values of standard deviation (SD) and reduction of global average percentage of COD, obtained through the leachate treatment by catalytic ozonation.

\begin{tabular}{|c|c|c|c|c|c|c|c|c|c|c|c|}
\hline & \multicolumn{4}{|c|}{$1^{\circ}$ Set } & \multicolumn{6}{|c|}{$2^{\circ}$ Set } & \\
\hline Experiment & Minimum & Maximum & Mean & SD & $\mathbf{N}$ & Minimum & Maximum & Mean & SD & $\mathbf{N}$ & $\begin{array}{c}\text { Global } \\
\text { Reduction(\%) }\end{array}$ \\
\hline 1 & 817.7 & 838.5 & 828.1 & 10.4 & 3 & 935.6 & $1,011.8$ & 979.7 & 31.9 & 4 & 11 \\
\hline 2 & 991.0 & $1,098.4$ & $1,061.5$ & 61.1 & 3 & 869.7 & 956.3 & 912.5 & 43.3 & 3 & 3 \\
\hline 3 & 699.9 & 880.1 & 790.0 & 127.4 & 2 & 866.3 & 921.7 & 890.5 & 28.4 & 3 & 17 \\
\hline 4 & 738.0 & 810.8 & 777.3 & 36.7 & 3 & 848.9 & 897.4 & 870.4 & 21.4 & 5 & 19 \\
\hline 5 & $1,060.3$ & $1,250.9$ & $1,178.1$ & 103.0 & 3 & 907.8 & 977.1 & 938.2 & 32.7 & 4 & 0 \\
\hline 6 & 973.7 & $1,126.1$ & $1,032.6$ & 81.9 & 3 & 904.4 & $1,119.2$ & 999.1 & 109.7 & 3 & 0 \\
\hline 7 & 706.9 & 738.0 & 722.4 & 22.1 & 2 & 918.2 & 994.5 & 956.4 & 38.5 & 4 & 17 \\
\hline 8 & 772.7 & 779.6 & 776.2 & 4.9 & 2 & 855.9 & 904.4 & 875.5 & 25.5 & 3 & 18 \\
\hline 9 & 894.0 & 894.0 & 894.0 & 0.1 & 2 & 758.8 & 814.3 & 778.5 & 31.1 & 3 & 17 \\
\hline 10 & 807.3 & 907.8 & 862.8 & 51.1 & 2 & 984.1 & $1,049.9$ & $1,014.4$ & 29.3 & 4 & 7 \\
\hline 11 & 745.0 & 852.4 & 803.9 & 54.5 & 3 & 796.9 & 921.7 & 843.7 & 54.3 & 4 & 19 \\
\hline 12 & 966.7 & $1,084.6$ & $1,021.0$ & 59.5 & 3 & 807.3 & 987.5 & 884.7 & 92.8 & 3 & 6 \\
\hline 13 & 724.2 & 734.6 & 729.4 & 74.4 & 2 & 765.8 & 880.1 & 822.9 & 80.9 & 2 & 23 \\
\hline 14 & $1,008.3$ & $1,043.0$ & $1,019.9$ & 20.0 & 3 & 838.5 & 973.7 & 909.0 & 57.3 & 4 & 5 \\
\hline 15 & 807.3 & 894.0 & 853.5 & 43.6 & 3 & 876.6 & 939.0 & 904.4 & 30.9 & 4 & 13 \\
\hline 16 & 994.5 & $1,098.4$ & $1,029.1$ & 60.0 & 3 & 890.5 & 921.7 & 907.0 & 15.3 & 4 & 5 \\
\hline
\end{tabular}

According to Table 3, higher values of reduction of COD (approximately $18 \%$ ) are observed when both of ozone flow (A) and concentration of $\mathrm{Fe}^{3+}$ (B) are adjusted to higher levels. The best result of the present organic material degradation in the leachate is conditioned to experiment number 13 with a reduction of COD equal to $23 \%$, with adjustments to the low and high levels for factors $\mathrm{A}$ and B, respectively. For experimental conditions 5 and 6, with low level for both factors $\mathrm{A}$ and $\mathrm{B}$, there was no degradation of the organic material in the leachate according to the reduction values of COD. With the aim of verifying the presence of outliers in the experimental set of results presented in Table 3, a study of probability of normal residuals was performed according to Figure 3.

In Figure 3, it can be verified that the residuals obtained for the experimental results of the $L_{16}$ experimental design are ordered in the normal mode and symmetrically distributed around zero, guaranteeing, then, the reliability of the experimental results (Table 3) with no presence of outliers.
According to Montgomery (2001), examination of the residuals should be an automatic part of any analysis of variance at the moment it guarantees the reliability of experimental results. Table 4 shows ANOVA of the factors involved in the exploratory study of in natura leachate treatment.

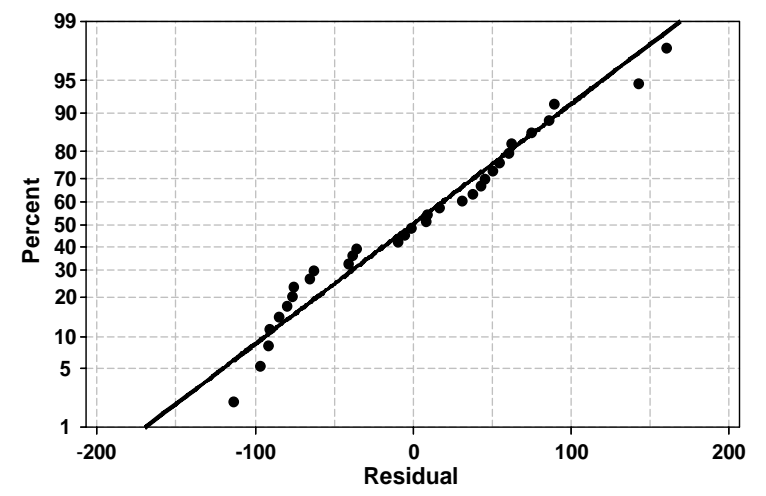

Figure 3: Probability of normal percentage against residuals obtained with values of $\mathrm{COD}$ in $\mathrm{L}_{16}$ Taguchi experiments.

Table 4: Analysis of Variance (ANOVA) obtained from the mean values of COD from the $L_{16}$ fractional factorial design.

\begin{tabular}{|c|c|c|c|c|c|}
\hline Source & Degrees of Freedom & Sum of Squares & Mean Square & $\mathbf{F}$ & p-value \\
\hline $\mathrm{A}$ & 1 & 34,748 & 34,748 & 4.89 & 0.037 \\
\hline B & 1 & 69,158 & 69,158 & 9.72 & 0.005 \\
\hline $\mathrm{C}$ & 1 & 750 & 750 & 0.11 & 0.748 \\
\hline $\mathrm{D}$ & 1 & $1,026.2$ & $1,026.2$ & 1.44 & 0.242 \\
\hline E & 1 & 33,743 & 33,743 & 4.74 & 0.040 \\
\hline $\mathrm{F}$ & 1 & 31,010 & 31,010 & 4.36 & 0.048 \\
\hline G & 1 & 733 & 733 & 0.10 & 0.751 \\
\hline $\mathrm{H}$ & 1 & 3,545 & 3,545 & 0.50 & 0.487 \\
\hline Error & 23 & 163,590 & 7,113 & & \\
\hline Total & 31 & 347,539 & & & \\
\hline
\end{tabular}


According to Analysis of Variance, Table 4, it is observed that the most significant factor studied in the $L_{16}$ design is the presence of ferric ion (factor B), with $F$ equal to 9.72 and $p$-value equal to 0.005 (confidence level of $99.5 \%$ ), indicating its catalytic action in the generation of hydroxil radicals and, consequently, radical-mediated degradation of organic material present in the effluent. Ozone flow (factor A) is also significant and nickel (factor E) and chromium (factor $\mathrm{F}$ ) ions with a minimum confidence level of $96.3 \%$ for factor $\mathrm{A} . \mathrm{Zn}^{2+}$ (factor C) and $\mathrm{Mn}^{2+}$ (factor D) ions did not show themselves to be statistically significant during the process, with $\mathrm{F}$ equal to 0.11 and 1.44 , respectively, indicating that these species do not have catalytic action for generation of hydroxyl radicals from molecular ozone. The selected levels for $\mathrm{pH}$ (factor G) were also not significant $(\mathrm{F}=0.1)$ for the mineralization of organic components of leachate. Finally, it was verified that the presence of the germicidal lamp (factor $\mathrm{H}$ ) did not influence the degradation of COD of the recalcitrant leachate, with $\mathrm{F}=0.5$.

Regarding the factor $\mathrm{pH}$, the solubilization of metallic ions in acidic medium has to be taken into consideration. For soluble iron, for example, there is: (1) at $\mathrm{pH} 7,90 \%$ of $\mathrm{Fe}^{2+}$ oxidizes in $1 \mathrm{~h}$, at $21^{\circ} \mathrm{C}$, with precipitation of the $\mathrm{Fe}^{3+}$ generated; (2) at $\mathrm{pH} 8$, therefore, $90 \%$ of $\mathrm{Fe}^{2+}$ oxidizes in $30 \mathrm{~s}$; (3) at $\mathrm{pH} 6$, the required time increases to $100 \mathrm{~h}$ (Vance, 1994). In spite of $\mathrm{Fe}^{3+}$ ion not being soluble, the presence of binding agents or chelates provides the solubilization of this and other species through the formation of soluble compounds. In a stabilized leachate of municipal landfills, there is a significant presence of the humic acids, highly recalcitrant and responsible for the transport of heavy metals from the interior of the landfills to the environment through the formation of stable compounds between the organic acids and metals (Kang et al., 2002, Wiszniowski et al., 2004). Basic $\mathrm{pH}$, therefore, as adapted to high level of factor $\mathrm{G}$ (Table 2), favors the solubilization of humic acid fraction and, consequently, their respective metallic compounds that would theoretically favor the action of radiation (Barros et al., 1993).

Comparing the values of $F$ test, it is observed that the ferric ion is approximately twice as significant in the degradation of COD as the nickel and chromic ions. It is also verified, in accordance with the current Brazilian legislation (CONAMA Resolution 357/05), that there is a bigger tolerance of $\mathrm{Fe}^{2+}\left(15.0 \mathrm{mg} \mathrm{L}^{-1}\right)$ than for $\mathrm{Ni}^{2+}\left(2.0 \mathrm{mg} \mathrm{L}^{-1}\right)$ and
$\mathrm{Cr}^{3+}$ (4.9 $\left.\mathrm{mg} \mathrm{L}^{-1}\right)$. This way, on the basis of the experimental results obtained (Table 4) and the current environment legislation (CONAMA Resolution 357/05), the use of ferric ion is more viable for the degradation of COD of the studied mature leachate.

The higher efficiency of $\mathrm{Fe}^{3+}$ ion relative to $\mathrm{Ni}^{2+}$ and $\mathrm{Cr}^{3+}$ ions can be derived from their concentration in the reaction medium (Table 2), being more available for activating molecular ozone and/or for faster degradation of the organic material degradation present at the leachate. Kinetic studies involving $\mathrm{Fe}^{3+}, \mathrm{Ni}^{2+}$ and $\mathrm{Cr}^{3+}$ will be performed later by our research group to discover why $\mathrm{Fe}^{3+}$ ions are more effective in the process.

Khan and Jung (2008) studied the degradation of $300 \mu \mathrm{g} \mathrm{L} \mathrm{L}^{-1}$ di-(2-ethyl hexyl) phthalate (DEHP) through homogeneous and heterogeneous catalytic ozonation. During the study of the homogeneous catalytic processes, the authors used transition metallic ions as catalysts $\mathrm{Fe}^{2+}, \mathrm{Co}^{2+}, \mathrm{Cr}^{3+}$ and $\mathrm{Mn}^{2+}$ with values of $\mathrm{pH} \mathrm{4,7,10}$ and 11 . The best results, among these, were reached with $\mathrm{Cr}^{3+}$ species, with degradation of $75 \%$ after $120 \mathrm{~min}$ of reaction. The worst results were reached with $\mathrm{Co}^{2+}$, with reduction of only $45 \%$ of recalcitrant compounds after 120 min of reaction. For soluble iron, the most efficient condition was in $\mathrm{pH} 2$, since higher values of $\mathrm{pH}$ showed precipitation of $\mathrm{Fe}^{3+}$.

After confirming the non-significant effect of UV radiation in the process of degradation of in natura leachate, according to $L_{16}$ method, the transmittance level of the quartz bulb used for protection of the germicidal lamp was verified. Figure 4 shows the spectrophotometric result of scanning quartz bulb pieces in the regions of UV-Vis.

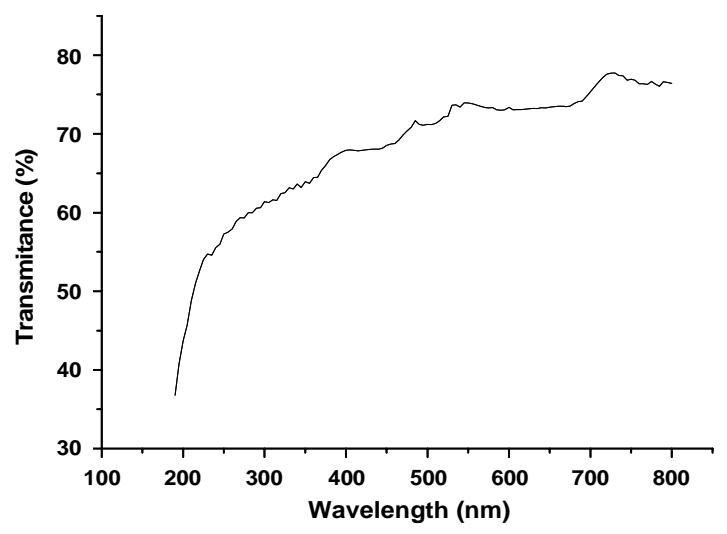

Figure 4: Spectrum of quartz bulbs used in the photo-irradiated process. 
According to Figure 4, at $254 \mathrm{~nm}$, the UV radiation transmittance is approximately $60 \%$, a considerable fraction of photons, around $40 \%$, being absorbed by the use of glass. It is also important to mention that the longer the photon wavelength the smaller the fraction absorbed by the material, with approximate values of $80 \%$ transmittance at $750 \mathrm{~nm}$. In Table 4, regarding to $\mathrm{L}_{16}$ Taguchi method, it was verified that the presence of UV radiation provided by the germicidal lamp was not significant in the degradation process of the organic material. Some points should be considered as justification of nonstatistical significance of factor $\mathrm{H}$ : i) the fraction of humic material present in leachate absorbs photons in the ultraviolet region, reducing the efficiency of photo-irradiated processes, which should be maximized in alkaline $\mathrm{pH}$; ii) no process of leachate pre-treatment was performed such as a filtration, particulate material representing one more negative influence on the photo-irradiated treatment, which was visibly reduced at alkaline $\mathrm{pH}$; iii) finally, the high absorptivity of photons by the quartz bulb according to Figure 4.

In order to propose an adjustment set of significant factor levels for the process of leachate catalytic ozonation, a graphical analysis of the main effects regarding the variables was performed. Figure 5 shows the graphs regarding the reduction of COD.
With the objective to diminish the value of COD, the following configuration of the factors already studied should be adopted according to the information in Figure 5: ozone flow, factor A, at the high level $\left(5 \mathrm{~L} \mathrm{~h}^{-1} ; 600 \mathrm{mg} \mathrm{h}^{-1} \mathrm{O}_{3}\right)$; concentration of ferric ion, factor $\mathrm{B}$, at the high level $\left(20 \mathrm{mg} \mathrm{L}^{-1}\right.$ $\mathrm{Fe}^{3+}$ ); concentration of manganese ion, factor $\mathrm{D}$, at the low level $\left(0.5 \mathrm{mg} \mathrm{L}^{-1}\right)$; concentration of nickel ion, factor $\mathrm{E}$, at the low level $\left(1.0 \mathrm{mg} \mathrm{\textrm {L } ^ { 1 }}\right)$, and concentration of chromic ion, factor $\mathrm{F}$, at the high level $\left(5.0 \mathrm{mg} \mathrm{L}^{-1}\right)$. The concentration of $\mathrm{Zn}^{2+}(\mathrm{C}), \mathrm{pH}$ of the reaction medium $(\mathrm{G})$ and $\mathrm{UV}(\mathrm{H})$ irradiation influence are not statistically significant according to ANOVA (Table 4), not influencing the mineralization of the organic material.

Taguchi's method, for what refers to Quality Engineering, constitutes one of the most important methods for defining experimental conditions, guaranteeing high quality products with the least possible cost and variance of the process involved. Among the tools used by Taguchi's method (experimental outline, ANOVA and signal-to-noise ratio), the study of signal-to-noise ratio informs the set of actions to be taken for adjusting the level of each factor, guaranteeing the least possible variation in the process or product in question (ASQ, 2008; Montgomery, 2001). Figure 6 shows the study of process variance by using the graph based on the average results for the signal-to-noise ratio $(\mathrm{S} / \mathrm{N})$.

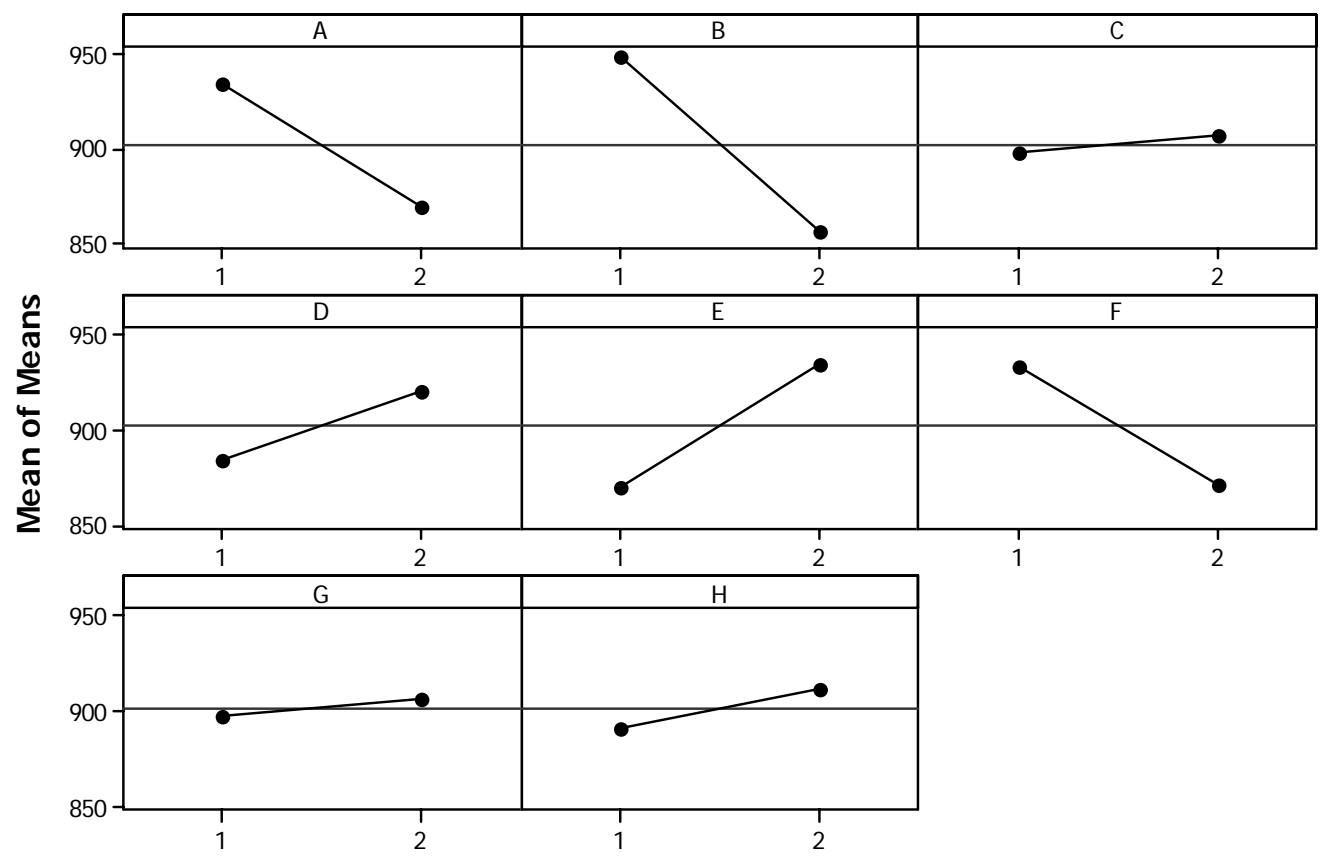

Figure 5: Main effects on COD of the factors used in the leachate treatment by homogeneous catalytic ozonation using $L_{16}$ experimental design. 


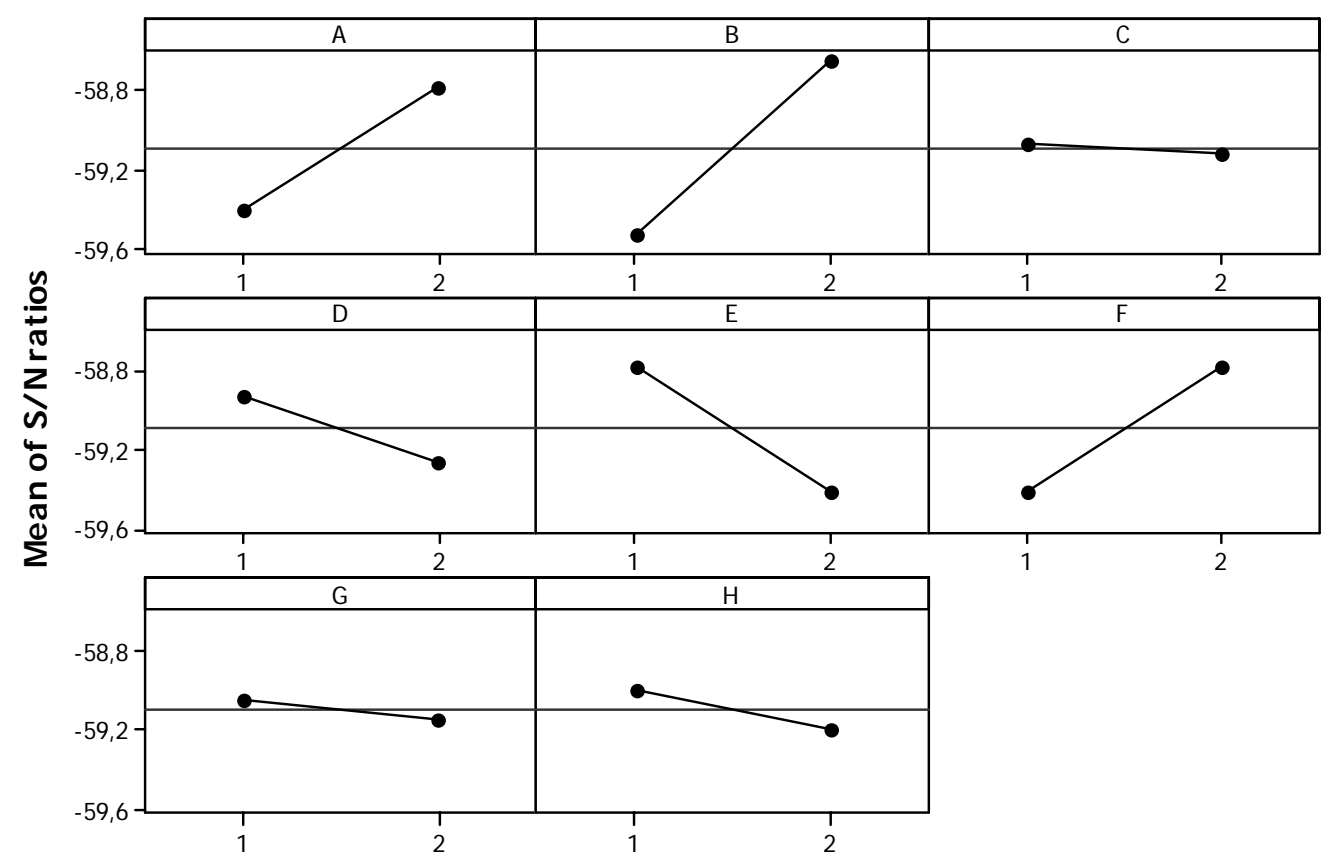

Figure 6: Average results in relation to the signal-to-noise ratio (adjustment condition 'smaller is better').

The results presented in Figure 6 were estimated from the condition "smaller is better", aimed at the degradation of COD results under each experimental condition from $L_{16}$ design. According to Figure 6, the best adjustment of the factor levels is through the following configuration: ozone flow, factor $\mathrm{A}$, at the high level $\left(5 \mathrm{~L} \mathrm{~h}^{-1} ; 600 \mathrm{mg} \mathrm{h}^{-1} \mathrm{O}_{3}\right)$; concentration of ferric ion, factor $\mathrm{B}$, at the high level $\left(20 \mathrm{mg} \mathrm{L}^{-1}\right.$ $\left.\mathrm{Fe}^{3+}\right)$; concentration of manganese ion, factor $\mathrm{D}$, at the low level $\left(0.5 \mathrm{mg} \mathrm{L}^{-1}\right)$; concentration of nickel ion, factor $\mathrm{E}$, at the low level $\left(1.0 \mathrm{mg} \mathrm{L}^{-1}\right)$, and concentration of chromic ion, factor $\mathrm{F}$, at the high level $\left(5.0 \mathrm{mg} \mathrm{L}^{-1}\right)$. The concentration of $\mathrm{Zn}^{2+}(\mathrm{C}), \mathrm{pH}$ of the reaction medium $(\mathrm{G})$ and $\mathrm{UV}(\mathrm{H})$ irradiation influence are not statistically significant according to ANOVA (Table 4). This configuration of level adjustments for factors is identical to the adjustment of main effects for average COD (Figure 5), showing that the configuration of level adjustments for factors $\mathrm{A}, \mathrm{B}, \mathrm{D}, \mathrm{E}$ and $\mathrm{F}$ are proposals that satisfy the conditions of higher reduction of organic material (mineralization) as well as lower variance of the chemical process and effluent treatments.
Finally, BOD values are determined with the aim at verifying the possibilities of increasing the biodegradability of leachate after the treatment by catalytic ozonation. Tables 5 and 6 show results from BOD analysis and the biotreatability ratio $\mathrm{BOD} / \mathrm{COD}$, respectively, from the samples of the leachate treated according to experiments of the Taguchi $L_{16}$ orthogonal array.

According to Table 5, there is a big oscillation in the analytical results presented for determinations of BOD. The results regarding the experiments number 1 to 4 (1st set), for example, present standard deviations of the same order as the mean values presented, showing the non-viability of BOD parameters as a response variable of the Taguchi $L_{16}$ orthogonal array. In Tables 5 and 6 it can be observed that the leachate treatment by catalytic ozonation with a reaction time of $30 \mathrm{~min}$ was not enough to promote a BOD/COD ratio closer to 0.4 , which is appropriate for the biological treatment of leachate (Chen et al., 2008). After the leachate treatment, a result was obtained for the maximum $\mathrm{BOD} / \mathrm{COD}$ ratio equal to 0.08 , in experiment 9 . 
Table 5: Minimum, maximum and mean values of BOD $\left(\mathrm{mg} \mathrm{L}^{-1}\right)$, and respective values of standard deviation (SD), obtained through the leachate treatment by homogeneous catalytic ozonation using $L_{16}$ fractional factorial

\begin{tabular}{|c|c|c|c|c|c|c|c|c|c|c|}
\hline & \multicolumn{5}{|c|}{$1^{\circ}$ Set } & \multicolumn{5}{|c|}{$2^{\circ}$ Set } \\
\hline Experiment & Minimum & Maximum & Mean & SD & $\mathbf{N}$ & Minimum & Maximum & Mean & SD & $\mathbf{N}$ \\
\hline 1 & 11 & 72 & 27 & 30 & 4 & 56 & 139 & 93 & 42 & 3 \\
\hline 2 & 26 & 76 & 52 & 26 & 4 & 70 & 80 & 75 & 7 & 2 \\
\hline 3 & 29 & 44 & 36 & 8 & 3 & 31 & 80 & 57 & 24 & 4 \\
\hline 4 & 5 & 69 & 32 & 31 & 4 & 69 & 87 & 78 & 12 & 2 \\
\hline 5 & 9 & 10 & 10 & 1 & 2 & 25 & 32 & 30 & 4 & 3 \\
\hline 6 & 25 & 91 & 53 & 33 & 4 & 26 & 35 & 30 & 6 & 2 \\
\hline 7 & 60 & 60 & 60 & 1 & 2 & 33 & 41 & 37 & 4 & 3 \\
\hline 8 & 28 & 36 & 34 & 4 & 4 & 53 & 54 & 53 & 1 & 2 \\
\hline 9 & 25 & 91 & 52 & 32 & 4 & 44 & 89 & 74 & 26 & 3 \\
\hline 10 & 17 & 49 & 33 & 23 & 2 & 51 & 56 & 54 & 4 & 2 \\
\hline 11 & 6 & 24 & 13 & 10 & 3 & 39 & 39 & 39 & 1 & 2 \\
\hline 12 & 22 & 54 & 37 & 16 & 3 & 47 & 67 & 54 & 12 & 3 \\
\hline 13 & 42 & 96 & 69 & 24 & 4 & 26 & 67 & 46 & 29 & 2 \\
\hline 14 & 18 & 44 & 31 & 18 & 2 & 24 & 26 & 25 & 2 & 2 \\
\hline 15 & 27 & 37 & 31 & 4 & 4 & $<5.0$ & $<5.0$ & $<5.0$ & - & 3 \\
\hline 16 & $<5.0$ & $<5.0$ & $<5.0$ & - & 2 & $<5.0$ & $<5.0$ & $<5.0$ & - & 3 \\
\hline
\end{tabular}

Table 6: Results of the BOD/COD ratio, using mean results from BOD and COD, for evaluation of leachate biotreatability after the treatment by homogeneous catalytic ozonation using $L_{16}$ fractional factorial.

\begin{tabular}{|c|c|c|c|}
\hline Experiment & $\begin{array}{c}\text { BOD } \\
\left(\mathrm{mg} \mathrm{L}^{-1}\right)\end{array}$ & $\begin{array}{c}\mathrm{COD} \\
\left(\mathrm{mg} \mathrm{L}^{-1}\right)\end{array}$ & BOD/COD \\
\hline 1 & 60 & 904 & 0.07 \\
\hline 2 & 63 & 987 & 0.06 \\
\hline 3 & 47 & 840 & 0.06 \\
\hline 4 & 55 & 824 & 0.07 \\
\hline 5 & 20 & 1,058 & 0.02 \\
\hline 6 & 41 & 1,016 & 0.04 \\
\hline 7 & 48 & 839 & 0.06 \\
\hline 8 & 43 & 826 & 0.05 \\
\hline 9 & 63 & 836 & 0.08 \\
\hline 10 & 43 & 939 & 0.05 \\
\hline 11 & 26 & 824 & 0.03 \\
\hline 12 & 46 & 953 & 0.05 \\
\hline 13 & 58 & 776 & 0.07 \\
\hline 14 & 28 & 964 & 0.03 \\
\hline 15 & 15 & 879 & 0.02 \\
\hline 16 & $<5.0$ & 967 & $<0.005$ \\
\hline
\end{tabular}

\section{CONCLUSIONS}

With the use of Taguchi $L_{16}$ experimental design (Quality tool), it was possible to identify the most significant factors in the reduction of COD, permitting in later studies the optimization of the treatment of leachate by homogeneous catalytic ozonation. It was verified that the transition metal ions $\mathrm{Fe}^{3+}, \mathrm{Ni}^{2+}$ and $\mathrm{Cr}^{3+}$ are statistically significant, as well as the oxidant $\mathrm{O}_{3}$, in the reduction of COD of recalcitrant leachate, indicating the catalytic action in the generation of hydroxyl radicals. Because ferric ions represent a lower environmental concern, with higher concentration permitted for discarding, and provided a better and efficient reduction of COD from the leachate, the use of ferric ions is technically and environmentally viable. The greater statistical significance of $\mathrm{Fe}^{3+}$ in the presence of $\mathrm{Ni}^{2+}$ and $\mathrm{Cr}^{3+}$ ions may be due to its higher concentration and reaction and/or kinetic order proportions will be verified later by the group. The photo-irradiated experiments were not efficient due to the physical (particle material in suspension) and chemical (humic and fulvic acids) characteristics of the leachate, allied to the high absoptivity of the quartz used (60\% transmittance). 


\section{ACKNOWLEDGMENTS}

The authors thank CAPES for the financial support and Jaime Alves Capucho for the semi-batch reactor project.

\section{REFERENCES}

Andreozzi, R., Caprio, V., Insola, A., Marotta, R., Tufano, V., The ozonation of pyruvic acid in aqueous solutions catalyzes by suspended and dissolved manganese, Water Research, 32, No. 5, 1492 (1998).

APHA, American Public Health Association, Standard Methods for Examination of Water and Wastewater (APHA, AWWA), 20th ed., New York, WPCF: 1999.

ASQ, American Society for Quality. Available at http://www.asq.org/about-asq/who-we-are/bio taguchi.html. Access in August (2008).

Assalin, M. R., Durán, N., Novas tendências para aplicação de ozônio no tratamento de resíduos: ozonização catalítica, Analytica, 26, 76 (2007).

Barros, A. M. A., Barros, A. B., Kerfourn, M. M., Study of humic and fulvic acids in recent lagoonal sediments, Journal of Brazilian Chemical Society, 14, No. 1, 1 (1993).

Battino, R., Oxygen and ozone solubilities, Solubility Data Series, Flanklin Book Company (1992).

Beltrán, F. J., Rivas, F. J., Montero-de-Espinosa, R., Iron type catalysts for the ozonation of oxalic acid in water, Water Research, 39, 3553 (2005).

Brazil, Ministry of Environment. Environmental National Council, CONAMA. Resolution N. 357, March 17, 2005. Available at www.mma.gov.br/ port/conama/res/res05/res35705.pdf. Access in August (2008).

CETESB, Determination of ammoniacal nitrogen in water: Nesslerization method with previous distillation: essay method. Norm L5.136 (1978).

CETESB, Determination of oil and grease in water: Solvent extraction method, Norm L5. 142 (1991).

CETESB, Determination of phenols in water: colorimetric method of 4-aminoantipirine: essay method, Norm L5.125 (1995).

Chen, S., Sun, D., Chung, J., Simultaneous removal of COD and ammonium from landfill leachate using an anaerobic-aerobic moving-bed biofilm reactor system, Waste Management, 28, 339 (2008).

Fifield, F. W., Kealey, D., Principles and Practice of Analytical Chemistry, 5th Ed., Blackwell
Science, p. 200 (2000).

Hill, G. R., Kinetics, Mechanism, and Activation Energy of the Cobaltous Ion Catalyzed Decomposition of Ozone, Journal of the American Chemical Society, 70, No. 4, 1306 (1948).

Hill, G. R., The Kinetics of the Oxidation of Cobaltous Ion by Ozone, Journal of the American Chemical Society, 71, No. 7, 2434 (1949).

Kang, K., Shin, H. S., Park, H., Characterization of humic substances present in landfill leachates with different landfill ages and its implications, Water Research, 36, 4023 (2002).

Kasprzyk-Hordern, B., Ziółek, M., Nawrocki, J., Catalytic ozonation and methods of enhancing molecular ozone reactions in water treatment, Applied Catalysis B: Environmental, 46, 639 (2003).

Khan, M. H., Jung, J. Y., Ozonation catalyzed by homogeneous and heterogeneous catalysts for degradation of DEHP in aqueous phase, Chemosphere, 72, No. 4, 690 (2008).

Kurniawan, T. A., LO, W., Chan, G. Y. S., Degradation of recalcitrant compounds from stabilized landfill leachate using a combination of ozone-GAC adsorption treatment, Journal of Hazardous Materials, B137, 443 (2006).

Legrini, O., Oliveros, E., Braun, A. M., Photochemical Processes for Water Treatment. Chem. Rev., 93, 671 (1993).

Legube, B., Leitner, N. K. V., Catalytic ozonation: a promising advanced oxidation technology for water treatment, Catalysis Today, 53, 61 (1999).

Lima, L. S., Izário Filho, H. J., Chaves, F. J. M., Determinação da demanda bioquímica de oxigênio para teores $<5 \mathrm{mg} \mathrm{L}^{-1} \mathrm{O}_{2}$, Analítica, 25, 52 (2006).

Mahmoud, A. and Freire, R. S., New methods for enhancing ozone efficiency on contaminated water treatment, Quimica Nova, 30, No. 1, 198 (2007).

Montgomery, D. C., Design and Analysis of Experiments, 5th ed., New York, John Wiley \& Sons, 2001.

Peixoto, A. L. C., Brito, R. A., Salazar, R. F. S., Guimarães, O. L. C., Izário Filho, H. J., Prediction of Chemical Oxygen Demand in natura landfill leachate doped with Fenton's reagent, using mathematical empiricism model obtained by full factorial design, Quimica Nova, 31, 1641 (2008).

São Paulo, State Government, Act 8.468 September 8, (1976) v. Available at http://www.cetesb.sp.gov.br/ Institucional/ documentos/ Dec8468.pdf. Access in December (2008). 
Selçuk, H., Eremektar, G., Meriç, S. The effect of pre-ozone oxidation on acute toxicity and inert soluble COD fractions of a textile finishing industry wastewater, Journal of Hazardous Materials, B137, 254 (2006).

Tizaoui, C., Bouselmi, L., Mansouri, L., Ghrabi, A., Landfill leachate treatment with ozone and ozone/hydrogen peroxide systems, Journal of Hazardous Materials, 140, 316 (2007).

Valdés, H., Murillo, F.A., Manoli, J. A., Zaror, C. A., Heterogeneous catalytic ozonation of benzothiazole aqueous promoted by volcanic sand, Journal of Hazardous Materials, 153, No. 3, 1036 (2008).

Vance, D. B., Iron - The environmental impact of a universal element, National Environmental Journal, 4, No. 3, 24 (1994).

Wiszniowski, J., Robert, D., Surmacz-Gorska, J., Miksch, K., Malato, S., Weber, J., Solar photocatalytic degradation of humic acids as a model of organic compounds of landfill leachate in pilot-plant experiments: influence of inorganic salts, Applied Catalysis B: Environment, 53, 127 (2004).

$\mathrm{Wu}, \mathrm{C}$., Kuo, C., Chang, C., Homogeneous catalytic ozonation of C.I. Reactive Red 2 by metallic ions in a bubble columm reactor, Journal of Hazardous Materials, 154, 748 (2008).

Wu, J. J., Wu, C., Ma, H., Chang, C., Treatment of landfill leachate by ozone-based advanced oxidation processes, Chemosphere, 54, 997 (2004). 